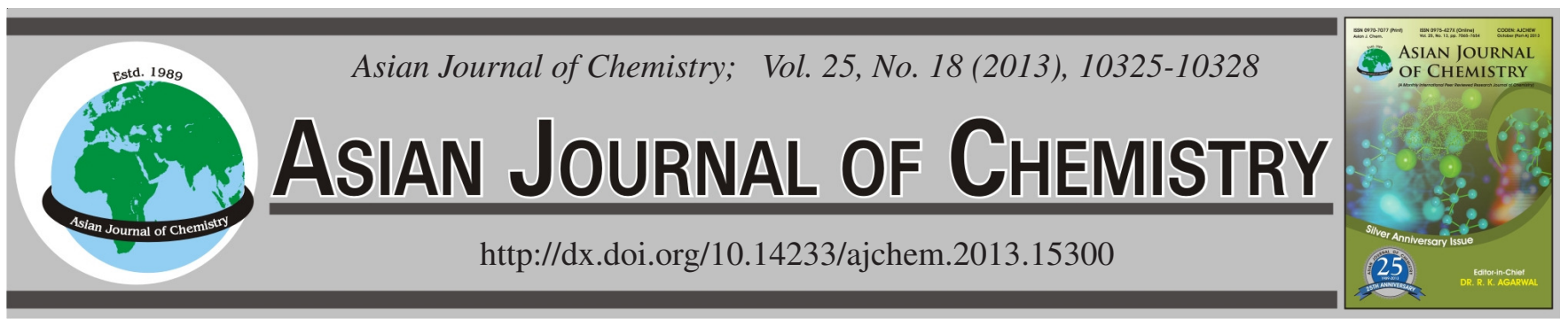

\title{
Effect of Zero-Valent Iron on the Anaerobic Biodegradation of 2,4-Dichlorophenol and 2,4,6-Trichlorophenol
}

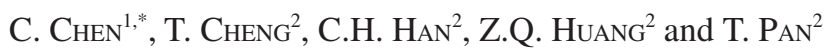

${ }^{1}$ School of Biology and Chemical Engineering, Jiangsu University of Science and Technology, Zhenjiang 212018, P.R. China

${ }^{2}$ Department of City Science, Jiangsu City Vocational College, Nanjing 210036, P.R. China

*Corresponding author: Tel: +86 511 85605157; E-mail: chenchen19830515@gmail.com

\begin{abstract}
The experiment was conducted to examine the effect of zero-valent iron $\left(\mathrm{Fe}^{0}\right)$ on the anaerobic biodegradation of 2,4-dichlorophenol and 2,4,6-trichlorophenol. To reveal the mechanism of action in $\mathrm{Fe}^{0}+$ cell system, the corrosion products of $\mathrm{Fe}^{0}$ under anaerobic condition was also investigated. The results showed that, the addition of $\mathrm{Fe}^{0}$ stimulated the 2,4-dichlorophenol and 2,4,6-trichlorophenol degradation effectively compared to the individual biotic cell use. The 2,4-dichlorophenol and 2,4,6-trichlorophenol was complete degraded inFe ${ }^{0}+$ cell system. $\mathrm{Fe}^{0}$ had some chemical reduction to 2,4-dichlorophenol and 2,4,6-trichlorophenol and that reduced the toxicity of contaminants to the microorganism. The $\mathrm{pH}$ in " $\mathrm{Fe}^{0}+$ cell" system was higher than that of the biotic cell system. The corrosion of $\mathrm{Fe}^{0}$ produced $\mathrm{OH}^{-}$and balanced the organic acid effectively. The corrosion products of $\mathrm{Fe}^{0}$ contained a majority of ferrous iron under anaerobic conditions and the production of ferric irons was relatively less.
\end{abstract}

Key Words: Chlorophenols, 2,4-Dichlorophenol, 2,4,6-Trichlorophenol, Zero-valent iron, Anaerobic biodegradation.

\section{INTRODUCTION}

Chlorophenols (CPs) are widely used in large quantities in industries for production of wood preservatives, pesticides, herbicides and plastic materials. Their discharge to the environment is of great concern because of their toxicity and potential carcinogenicity $^{1,2}$. Five chlorophenols are listed by the US Environmental Protection Agency (US EPA) as priority pollutants, such as 2,4-dichlorophenol, 2,4,6-trichlorophenol and pentachlorophenol (PCP). Due to their high toxicity, persistence and bioaccumulation in aquatic organisms, nowadays, their disposal has become a major environmental concern ${ }^{3,4}$. Said et al. ${ }^{5}$ indicated that anaerobic transformation could be considered as a promising means for bioremediation treatments of persistently polluted environments. Nicholson et al. ${ }^{6}$ suggested that the anaerobic digester sludge transformed pentachlorophenol by sequential ortho dechlorinations to produce 2,3,4,5tetrachlorophenol $(2,3,4,5-\mathrm{TeCP})$ and 3,4,5-trichlorophenol (3,4,5-TCP). Zero-valent iron has also shown great versatility in treating contaminants such as halogenated organic compounds via chemical reduction. Matheson \& Tratyek $^{7}$ and Kim \& Carraway ${ }^{8}$ advised that $\mathrm{Fe}^{0}$ reacted directly with chlorinated compounds to achieve dechlorination, which decreased the toxicity of contaminants. However, due to the large activation energy barrier, chemical reduction is too slow for $\mathrm{Fe}^{0}$ to be used in situ for remediation.

The survey of the literature indicated that, the addition of $\mathrm{Fe}^{0}$ in microbial system could stimulate the reductive dechlorination of chlorinated aliphatics ${ }^{9-12}$. Rysavy et al. ${ }^{13}$ demonstrated that $\mathrm{Fe}^{0}$ could as a source of hydrogen for anaerobic polychlorinated biphenyl dechlorinators. Cheng et al. ${ }^{14}$ demonstrated that $\mathrm{Fe}^{0}$ supported microbial reductive dechlorination of 2,4-dichlorophenol. The objective of this research was to determine if $\mathrm{Fe}^{0}$ could stimulate the anaerobic biodegradation of 2,4-dichlorophenol and 2,4,6-trichlorophenol and if so, to reveal the mechanism of action in the combined $\mathrm{Fe}^{0}$ and cell system.

\section{EXPERIMENTAL}

Microorganisms: A mixed anaerobic sludge used for this research was developed from a full-scale internal circulation reactor treating dye wastewater. The anaerobic sludge was first fed with 3,000 mg of glucose per liter as the carbon source for two weeks, which enhanced the biological activity and COD removal rate was over $85 \%$ before the experiments.

General approach: Batch experiments were conducted using serum bottles $(250 \mathrm{~mL})$ at $37^{\circ} \mathrm{C}$. The microorganism was transferred to serum bottle with $50 \mathrm{~mL}$ nutrient medium 
and $1 \mathrm{~mL}$ trace element solution. The nutrient medium in bottle contained (mg L-1 ${ }^{-1} \mathrm{KH}_{2} \mathrm{PO}_{4} 54, \mathrm{~K}_{2} \mathrm{HPO}_{4} 70, \mathrm{NH}_{4} \mathrm{Cl} 106$, $\mathrm{CaCl}_{2} \cdot 2 \mathrm{H}_{2} \mathrm{O} 15, \mathrm{MgCl}_{2} \cdot 6 \mathrm{H}_{2} \mathrm{O} 20$; the trace element solution contained (mg L-1 $): \mathrm{CoCl}_{2} \cdot 6 \mathrm{H}_{2} \mathrm{O} 500, \mathrm{NiCl}_{2} \cdot 6 \mathrm{H}_{2} \mathrm{O} 50, \mathrm{Na}_{2} \mathrm{SeO}_{3}$ 50, $\mathrm{CuCl}_{2} \cdot 2 \mathrm{H}_{2} \mathrm{O} 30, \mathrm{ZnCl}_{2} 50, \mathrm{H}_{3} \mathrm{BO}_{3} 50, \mathrm{MnCl}_{2} \cdot 4 \mathrm{H}_{2} \mathrm{O} 500$, $\left(\mathrm{NH}_{4}\right)_{6} \mathrm{Mo}_{7} \mathrm{O}_{24} \cdot 2 \mathrm{H}_{2} \mathrm{O} 10$. Zero-valent iron used in this study was iron fillings and iron fillings was added directly to the bottle. Each bottle was spiked with 2,4-chlorophenol and 2,4,6trichlorophenol stock solution to give an initial concentration of 20 and $10 \mathrm{mg} \mathrm{L}^{-1}$, respectively. $\mathrm{NaHCO}_{3}\left(1,000 \mathrm{mg} \mathrm{L}^{-1}\right)$ was also added to maintain a buffering capacity. Bottles were then filled with deionized water and $\mathrm{pH}$ was adjusted with $\mathrm{HCl}$ and $\mathrm{NaOH}$ solution. The liquid was purged with nitrogen for 10 min to remove any residual dissolved oxygen completely then bottles were sealed with rubber stoppers and placed on a platform shaker and shaken continuously at $120 \mathrm{rpm}$ over the course of experiments.

The experiment was first conducted to investigate the effect of $\mathrm{Fe}^{0}$ on the anaerobic biodegradation of 2,4-dichlorophenol and 2,4,6-trichlorophenol by a mixed culture. Biotic culture was also conducted to evaluate the effect of individual microorganism on the anaerobic biodegradation of 2,4dichlorophenol and 2,4,6-trichlorophenol. In addition, to study the complicated degradation mechanism of " $\mathrm{Fe}^{0}+$ cell" system, effect of individual zero-valent iron on the chemical degradation of 2,4-dichlorophenol and 2,4,6-trichlorophenol was investigated. Changes of $\mathrm{pH}$ during the reactive process and the production of iron ion in " $\mathrm{Fe}^{0}+$ cell" system were evaluated by monitoring $\mathrm{pH}$, total iron ion, ferrous iron $\left(\mathrm{Fe}^{2+}\right)$ and ferric iron $\left(\mathrm{Fe}^{3+}\right)$.

Anaerobic degradation of 2,4-dichlorophenol and 2,4,6-trichlorophenol in "Fe ${ }^{0}+$ cell", "Biotic cell" and individual $\mathbf{F e}^{0}$ system: An experiment was to investigate the effect of $\mathrm{Fe}^{0}$ on the anaerobic biodegradation of 2,4dichlorophenol and 2,4,6-trichlorophenol was conducted in a $250 \mathrm{~mL}$ serum bottle and bottle contained $1 \mathrm{~g} \mathrm{~L}^{-1}$ iron fillings and a mixed culture. To compare the effect of individual culture on the anaerobic biodegradation of 2,4-dichlorophenol and 2,4,6-trichlorophenol, biotic culture was introduced to experiment separately and the initial concentration of 2,4dichlorophenol and 2,4,6-trichlorophenol was 20 and $10 \mathrm{mg}$ $\mathrm{L}^{-1}$, respectively. Meanwhile, a bottle was prepared for individual $\mathrm{Fe}^{0}$ treatment. Bottle prepared for biotic culture treatments contained live microorganism and no $\mathrm{Fe}^{0}$ and $\mathrm{Fe}^{0}$ chemical treatments contained iron fillings and no live microorganism. The initial $\mathrm{pH}$ was adjusted to 7 in all experiments. The biomass concentration in each bottle was $355 \mathrm{mg} \mathrm{L}^{-1}$ based on the volatile suspended solids (VSS) contents of anaerobic sludge. Bottles were sampled periodically for 2,4dichlorophenol, 2,4,6-trichlorophenol, $\mathrm{pH}$, total iron ion, ferrous iron and ferric iron.

Analytical methods: The sample was taken from bottle using a glass syringe. Analysis for 2,4-dichlorophenol and 2,4,6-trichlorophenol were performed using a Agilent LC-1260 HPLC system, equipped with a Lichrospher C18 inverse phase column. An L-2400 UV detector was used for the analysis and the detection wavelength was $290 \mathrm{~nm}$. The HPLC mobile phase was the mixture of purified water $(15 \%)$ and methanol
(85\%) at flow rate of $1 \mathrm{~mL} \mathrm{~min}^{-1}$. The injection volume was $10 \mu \mathrm{L}$ with an auto-sampler. Prior to HPLC analysis, sample solutions were filtered by $0.45 \mu \mathrm{m}$ membrane. The $\mathrm{pH}$ was determined by PHS-3C acidometer. Ferrous iron and ferric iron was measuring by a way of phenanthroline spectrophotometric method. The biomass was measured as volatile suspended solids using standard methods.

\section{RESULTS AND DISCUSSION}

Effect of $\mathrm{Fe}^{0}$ on the anaerobic biodegradation of 2,4dichlorophenol and 2,4,6-trichlorophenol: The test was to investigate the effect of $\mathrm{Fe}^{0}$ on the anaerobic biodegradation of 2,4-dichlorophenol and 2,4,6-trichlorophenol by a mixed culture. Meanwhile, the biodegradation of individual biotic culture for 2,4-dichlorophenol and 2,4,6-trichlorophenol was also investigated. Fig. 1 showed the degradation of 2,4dichlorophenol and 2,4,6-trichlorophenol in " $\mathrm{Fe}^{0}+\mathrm{cell}$ " system and individual biotic cell system. Fig. 1 indicated that anaerobic microorganism had the potential of degrading 2,4dichlorophenol and 2,4,6-trichlorophenol and the biotic cell began to degrade 2,4-dichlorophenol and 2,4,6-trichlorophenol almost without lag phase. In the degradation period of $170 \mathrm{~h}$, the degradation rate of 2,4-dichlorophenol and 2,4,6trichlorophenol by biotic cell was 39.2 and $56 \%$, respectively. The degradation rate was improved obviously in 310 h, 2,4dichlorophenol and 2,4,6-trichlorophenol degradation rate was 44.2 and $91.5 \%$, respectively. When the biotic cell degraded 2,4-dichlorophenol and 2,4,6-trichlorophenol in $360 \mathrm{~h}$, the degradation rate of 2,4-dichlorophenol was $49.2 \%$ and the 2,4,6-trichlorophenol was completely degraded.

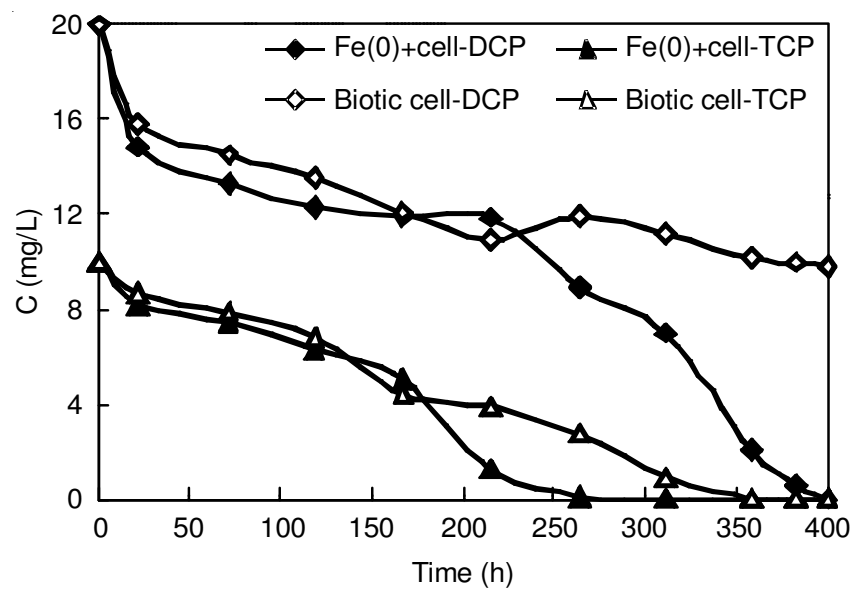

Fig. 1. Degradation of 2,4-dichlorophenol (DCP) and 2,4,6-trichlorophenol (TCP) in " $\mathrm{Fe}^{0}+$ cell" and individual "biotic cell" system

In contrast, in the degradation period of $170 \mathrm{~h}$, the degradation rate of 2,4-dichlorophenol and 2,4,6-trichlorophenol in " $\mathrm{Fe}^{0}+$ cell" system almost the same with the biotic cell system. However, with the extension of reaction time, the degradation rate of chlorophenols in " $\mathrm{Fe}^{0}+$ cell" system increased rapidly. When the degradation period was extended to $310 \mathrm{~h}$, the 2,4-dichlorophenol degradation rate was increased to $65.1 \%$ and the 2,4,6-trichlorophenol was completely degraded. In the degradation period of $360 \mathrm{~h}$, the 2,4dichlorophenol degradation rate was $89.9 \%$. The time needed 
for complete degradation of 2,4-dichlorophenol and 2,4,6trichlorophenol was $400 \mathrm{~h}$ in " $\mathrm{Fe}^{0}+$ cell" system. Fig. 1 suggested that, "Fe ${ }^{0}+$ cell" system stimulated the degradation of 2,4dichlorophenol and 2,4,6-trichlorophenol effectively compared to the individual biotic cell use.

Fig. 2 showed the chemical degradation of 2,4dichlorophenol and 2,4,6-trichlorophenol by $\mathrm{Fe}^{0}$. Fig. 2 showed that $\mathrm{Fe}^{0}$ had some chemical reduction to 2,4-dichlorophenol and 2,4,6-trichlorophenol. In the reaction time of $20 \mathrm{~h}$, the degradation rate of 2,4-dichlorophenol and 2,4,6-trichlorophenol was 11.7 and $8.4 \%$, respectively. When the reaction time was extended to $120 \mathrm{~h}$, the degradation rate of chlorophenols was slightly increased. The 2,4-dichlorophenol and 2,4,6-trichlorophenol degradation rate was 19 and $16.4 \%$, respectively. However, the degradation rate of 2,4-dichlorophenol and 2,4,6-trichlorophenol was almost unchanged with the increasing of reaction time. The toxicity of chlorophenols could to a certain degree be reduced by the chemical reduction of $\mathrm{Fe}^{0}$ and accelerated the microbial activities to degrade the 2,4dichlorophenol and 2,4,6-trichlorophenol.

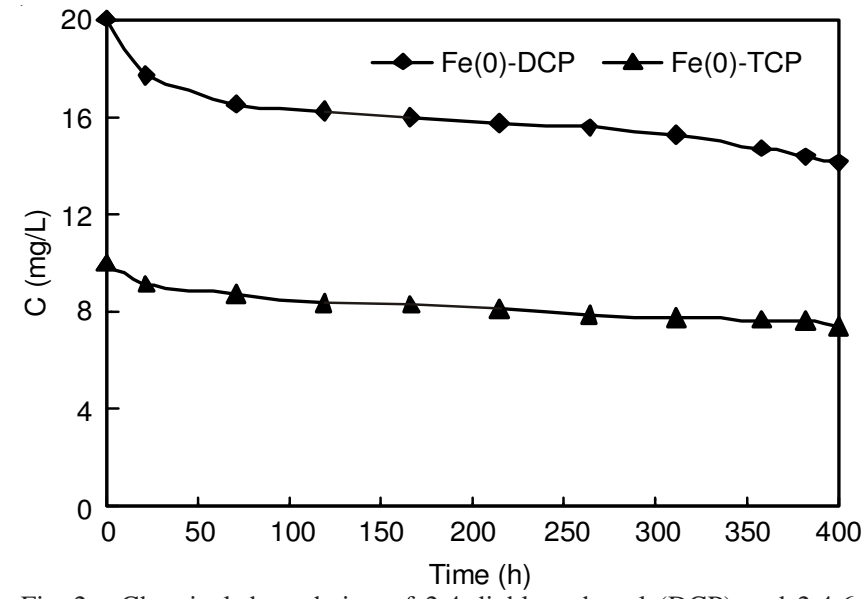

Fig. 2. Chemical degradation of 2,4-dichlorophenol (DCP) and 2,4,6trichlorophenol (TCP) in individual $\mathrm{Fe}^{0}$ system

Changes of $\mathrm{pH}$ during the reactive process in " $\mathrm{Fe}^{0}+$ cell" system: To investigate the action mechanism for 2,4dichlorophenol and 2,4,6-trichlorophenol in " $\mathrm{Fe}^{0}+$ cell" system, the experiment determined changes of $\mathrm{pH}$, the production of $\mathrm{Fe}^{2+}$ and $\mathrm{Fe}^{3+}$ during the reaction process. Fig. 3 showed changes of $\mathrm{pH}$ during the reaction process in " $\mathrm{Fe}^{0}+$ cell" system and individual biotic cell system. Fig. 3 indicated that the addition of $\mathrm{Fe}^{0}$ greatly improved the $\mathrm{pH}$ of the reaction process. The $\mathrm{pH}$ of biotic cell system was decreased at the beginning of the reaction and the $\mathrm{pH}$ was 6.22 in the reaction time of $70 \mathrm{~h}$. The $\mathrm{pH}$ was increased gradually with the prolongation of reaction time. When the reaction time was $265 \mathrm{~h}$, the $\mathrm{pH}$ of biotic cell system was increased to 6.57. In the following reaction process, the $\mathrm{pH}$ fluctuated slightly. Fig. 3 also showed that the $\mathrm{pH}$ during the reaction process in " $\mathrm{Fe}^{0}+$ cell" system was always higher than that of the biotic cell system. In the reaction time of $70 \mathrm{~h}$, the $\mathrm{pH}$ of " $\mathrm{Fe}^{0}+$ cell" system was 7.06 . In addition, the $\mathrm{pH}$ was 6.89 in $265 \mathrm{~h}$. In the whole reaction process, the $\mathrm{pH}$ maintained at 7 in " $\mathrm{Fe}^{0}+$ cell" system. Dai et $a l .{ }^{15}$ suggested that the acid-producing bacterial could achieve the fermentation of glucose and produced a large number of

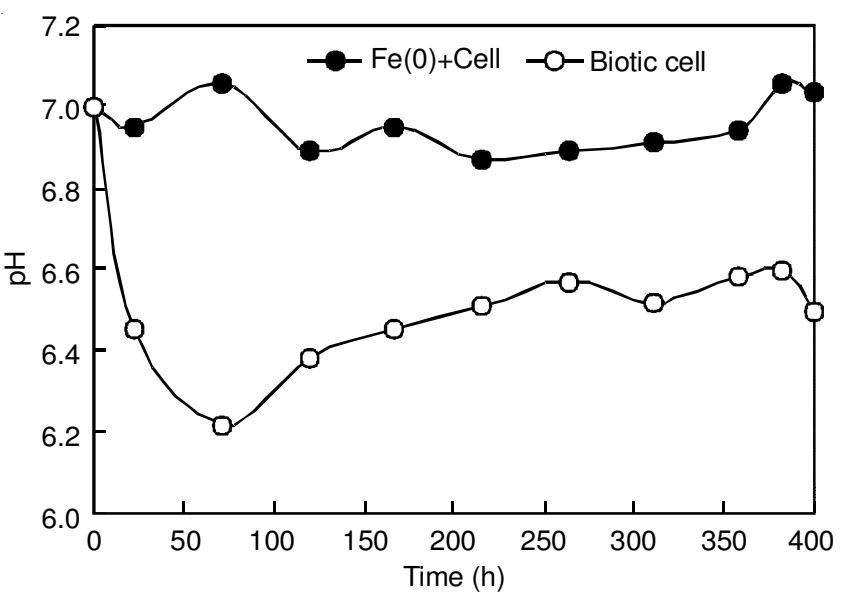

Fig. 3. Changes of $\mathrm{pH}$ during the reaction process in "Fe ${ }^{0}+$ cell" and individual "biotic cell" system

organic acid. The accumulation of organic acid in microbial system was disadvantageous for the degradation of chlorophenols. In the experiment, the individual biotic cell system produced organic acid by anaerobic fermenting organic substances and resulted in the decline of $\mathrm{pH}$. In contrast, the corrosion of $\mathrm{Fe}^{0}$ produced $\mathrm{OH}^{-}$in " $\mathrm{Fe}^{0}+$ cell" system and that balanced the organic acid produced by viable organism effectively. Therefore, the " $\mathrm{Fe}^{0}+$ cell" system achieved higher degradation rate for 2,4-dichlorophenol and 2,4,6-trichlorophenol (Fig. 1).

Production of iron ion in " $\mathrm{Fe}^{0}+$ cell" system: The corrosion of iron under anaerobic condition produces $\mathrm{OH}^{-}$, fer-rous iron and ferric iron. Fig. 4 showed the production of total iron ion i.e., ferrous iron and ferric iron in " $\mathrm{Fe}^{0}+$ cell" system. Fig. 4 indicated that the corrosion products of zero-valent iron contained a large number of ferrous iron and a small quantity of ferric iron under anaerobic conditions. In the combined system of $\mathrm{Fe}^{0}$ and cell, the concentration of total iron ion and ferrous iron was 65.1 and $51.2 \mathrm{mg} \mathrm{L}^{-1}$ at the end of the reaction, respectively. But the corrosion product of ferric iron was 13.9 $\mathrm{mg} \mathrm{L}^{-1}$. The reaction active metal of $\mathrm{Fe}^{0}$ is relatively strong, $\mathrm{E}_{0}$ $\left(\mathrm{Fe}^{2+} / \mathrm{Fe}^{0}\right)=-0.440 \mathrm{~V}$. In the process of $\mathrm{Fe}^{0}$ conversed to $\mathrm{Fe}^{2+}$, it released electronic constantly. However, $\mathrm{E}_{0}\left(\mathrm{Fe}^{3+} / \mathrm{Fe}^{2+}\right)=$ $0.771 \mathrm{~V}$, the capacity of $\mathrm{Fe}^{2+}$ conversed to $\mathrm{Fe}^{3+}$ was limited and completing the conversion of $\mathrm{Fe}^{3+}$ was relatively difficult.

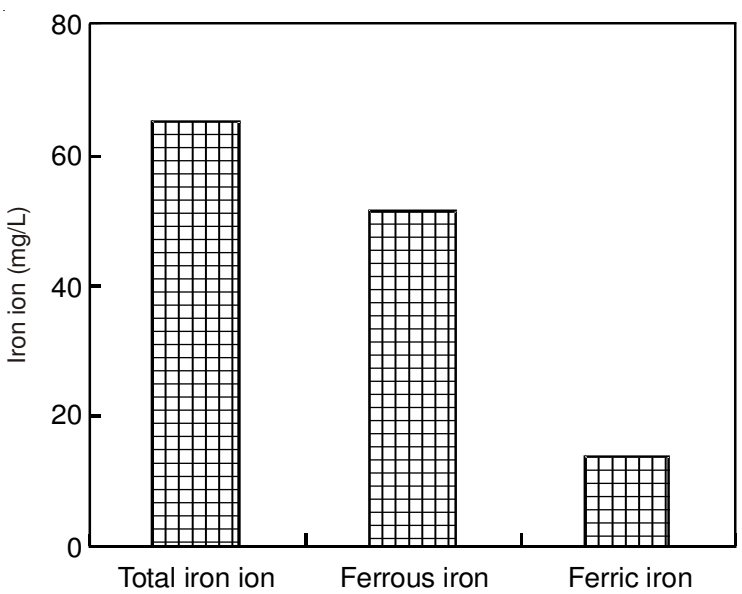

Fig. 4. Production of total iron ion, ferrous iron and ferric iron in " $\mathrm{Fe}^{0}+$ cell" system 


\section{Conclusion}

" $\mathrm{Fe}^{0}+$ cell" system accelerated the degradation of 2,4dichlorophenol and 2,4,6-trichlorophenol effectively compared to the individual biotic cell use. In the early degradation period, the degradation rate of 2,4-dichlorophenol and 2,4,6trichlorophenol in " $\mathrm{Fe}^{0}+$ cell" system almost the same with the biotic cell system. But the degradation rate of contaminants in " $\mathrm{Fe}^{0}+$ cell" system increased rapidly with the extension of reaction time. The 2,4-dichlorophenol and 2,4,6-trichlorophenol was degraded completely in $400 \mathrm{~h}$ in the combined $\mathrm{Fe}^{0}$ and cell system. $\mathrm{Fe}^{0}$ had some chemical reduction to 2,4dichlorophenol and 2,4,6-trichlorophenol and that reduced the toxicity of chlorophenols to live culture. The addition of $\mathrm{Fe}^{0}$ greatly improved the $\mathrm{pH}$ of reaction process. The $\mathrm{pH}$ in " $\mathrm{Fe}^{0}+$ cell" system was higher than that of the biotic cell system. The live culture produced organic acid by anaerobic fermenting organic substances. The corrosion of $\mathrm{Fe}^{0}$ produced $\mathrm{OH}^{-}$and that balanced the organic acid effectively in the system of $\mathrm{Fe}^{0}$ and cell. The corrosion products of $\mathrm{Fe}^{0}$ under anaerobic conditions contained a majority of ferrous iron and the production of ferric irons was relatively less.

\section{ACKNOWLEDGEMENTS}

The authors thanks for fund from Science Foundation of Jiangsu Colleges and Universities (Project No. 13KJB610005).

\section{REFERENCES}

1. M. Czaplicka, Sci. Total Environ., 322, 21 (2004).

2. G. Collins, C. Foy, S. McHugh and V. O'Flaherty, FEMS Microbiol. Ecol., 53, 167 (2005).

3. A.M. Montiel, F.J. Fernandez, J. Marcial, J. Soriano, J. Barrios-González and A. Tomasini, Biotechnol. Lett., 26, 1353 (2004).

4. A. Breitenstein, A. Saano, M. Salkinoja-Salonen, J.R. Andreesen and U. Lechner, Arch. Microbiol., 175, 133 (2001).

5. S. El Fantroussi, H. Naveau and S.N. Agathos, Biotechnol. Progr., 14, 167 (1998)

6. D.K. Nicholson, S.L. Woods, J.D. Istok and D.C. Peek, Appl. Environ. Microbiol., 58, 2280 (1992).

7. L.J. Matheson and P.G. Tratyek, Environ. Sci. Technol., 28, 2045 (1994).

8. O. Kim and E.R. Carraway, Environ. Sci. Technol., 34, 2014 (2000).

9. L.J. Weathers, G.F. Parkin and P.J. Alvarez, Environ. Sci. Technol., 31, 880 (1997).

10. K.J. Lampron, P.C. Chiu and D.K. Cha, Water Res., 35, 3077 (2001).

11. T. Lee, T. Tokunaga and A. Suyama and K. Furukawa, J. Biosci. Bioeng., 453, 92 (2001).

12. H. Rosenthal, L. Adrian and M. Steiof, Chemosphere, 55, 661 (2004).

13. J.P. Rysavy, T. Yan and P.J. Novak, Water Res., 39, 569 (2005).

14. T. Cheng, Y.Z. Dai, C. Chen and Z.Q. Huang, Asian J. Chem., 24, 2579 (2012).

15. Y.Z. Dai, H.C. Shi and J.P. Ji, Environ. Sci., 21, 40 (2000) (in Chinese). 